\title{
BRIAN MCKECHNIE ALI 'STARAJMO SE POZITIVNO'
}

\section{O Univerzi Strathclyde in njenem Inštitutu za študije o starejših, njegovih programih ter o podobnosti s Slovensko univerzo za tretje življenjsko obdobje}

B rian McKechnie je direktor Inštituta za študije o starejših (angl. Senior Studies Institute) na Univerzi Strathclyde v Glasgowu. Brian McKechnie pa je tudi oče šestih otrok, kar je, tako so mi zatrdili, na Škotskem nekaj povsem običajnega. Brian je mladost preživel v Liceju za nadarjene (zgolj!) dečke, nedaleč od svojega današnjega inštituta in nedaleč od slovite založniške hiše Collins, oziroma njenih skladišč, kjer si je kot študent služil kruh.

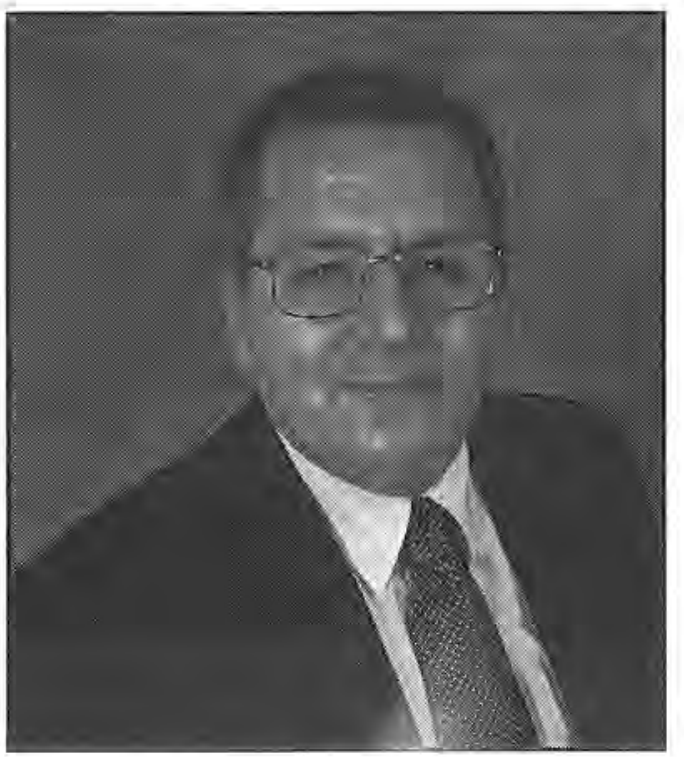

Po zaključenem študiju arheologije ga je pot vodila naokrog. Dlje časa je delal kot vodja kadrovske službe v neki veliki trgovski hiši. Tam je dodobra spoznal svet poslovanja in trgovanja in tako danes tudi ve, kje in kako pridobiti sredstva za delovanje svojega inštituta. Pri tem se zanese, pravi, na svoj takrat ustvarjeni socialni krog. $\mathrm{Pa}$ ne le to! Med vsemi vprašanji starejših ga prav posebej zanimajo vprašanja njihovega zaposlovanja. Kot kadrovski direktor se je nekega dne srečal tudi z vprašanjem, kako izobraževati in zaposlovati invalidne osebe. Pričel je poglabljati znanje o psiholoških, socialnih, ekonomskih in izobraževalnih vprašanjih te skupine. "Ko pa pričnemo razumevati, v čem je posebna kultura takšne skupine, nas prične zanimati tudi posebna kultura drugih skupin. In mene so pričeli zanimati starejši," je povedal.

Od velike trgovske hiše ga je pot vodila $\mathrm{v}$ Workers'Association (slov. Delavsko društvo). Ta velika organizacija je $\mathrm{v}$ anglosaškem svetu poznana po izobraževanju delavcev. In tako je Brian združil svoja znanja in izkušnje iz poslovnega sveta, znanja o skupinah s posebnimi potrebami, znanja o zaposlovanju in izobraževanju odraslih. Pridobil je podlago 
za nastanek vsaj nekaterih zdajšnjih usmeritev Inštituta za študije o starejših. Za kakšen inštitut torej gre?

\section{INŠTITUT JE NASTAL, KO SO MNOGE STAREIŠE ODPUSTILI Z DELA}

Inštitut za študije o starejših na Univerzi Strathclyde je bil uradno ustanovljen leta 1991 - šest let po tistem, ko smo ustanovili Slovensko univerzo za tretje življenjsko obdobje - kot enota njenega Centra za vseživljenjsko učenje. Tega leta je obseg dela s starejšimi močno narasel in to $\mathrm{v}$ času, ko je bila v Veliki Britaniji le peščica podobnih izobraževalnih programov za starejše. In tedaj se je na Inštitutu oglasil gostujoči kanadski profesor, navdušeno pripovedujoč o novih dosežkih geragogike na njegovi univerzi, pa tudi o nuji, da spričo hitro rastočega števila starejših nastane izobraževanje zanje. Sledili so obiski priznanih profesorjev z Univerze $v$ Londonu, ki so $\mathrm{s}$ pripovedjo o svojih dosežkih prepričali močno črnogledi in nejeverni senat univerze. Ti začetki $\mathrm{v}$ mnogočem spominjajo na začetke Slovenske univerze za tretje življenjsko obdobje, ko smo se srečevali s pripombami, da "naj končno pridemo dol z oblakov ..." in s hudo nejevernostjo. V primeru izobraževanja starejših odraslih je ta nejevernost še toliko večja, kajti stereotipi o starejših jih rišejo kot nekoristne za družbo, nesposobne razvoja in neučljive ...! 12

Ko so pobudniki Inštituta pridobili prva državna in zasebna sredstva za prenovo prostorov in so zaposlili deset delavcev, se je razvejal tudi program. Uvedli so izobraževalne programe za starejše odrasle, za njihovo osebnostno, intelektualno in poklicno rast; programe za razvoj prostovoljstva, programe za razvoj spretnosti, ki jih starejši potrebujejo pri iskanju zaposlitve. Uvedli so usposa- bljanje prostovoljcev in oseb, ki poklicno delajo s starejšimi, raziskovalno učenje in participativno raziskovanje, lokalno, nacionalno in internacionalno povezovanje s sorodnimi organizacijami. Zanimivo je, da ima tudi Slovenska univerza za tretje življenjsko obdobje vsaj po ciljih, če ne tudi vsebinah, enake sklope programov, četudi jih je razvijala po lastnih poteh, odzivajoč se predvsem na potrebe svojih slušateljev in okolja.

Večina študentov na Inštitutu se odloči za 20 do 40 ur predavanj $v$ ěasovnem obdobju 10 do 20 tednov. $V$ tem je Slovenska univerza drugačna, saj nudi svojim slušateljev večinoma trikrat večji obseg izobraževalnih ur. Inštitut pa je poseben v tem, da organizira tudi akreditirani študij o vprašanjih starejših, pa še poldnevne "seminarje za pokušino", obiskovanje izbranih dodiplomskih programov znotraj Univerze Strathclyde in izredni študij na dodiplomski stopnji.

$\mathrm{Z}$ denarno pomočjo Mestne občine nekatera predavanja potekajo $\mathrm{v}$ marginaliziranem mestnem okolju in družbenih skupinah ter na podeželju. Tako v takšnih okoljih prebivalci odkrivajo, denimo, zgodovino žensk, ali pa se učijo nemško. Tudi Slovenska univerza ponekod organizira "izobraževanje po okoliških vaseh", ki je nalezljivo zanetilo navdušenje za izobraževanje odraslih tudi pri mlajših.

Projekt učenja tradicionalnega tkanja so razširili na otoku Arran. Znanja, ki so si jih starejši pridobili, so potlej prenesli na mlade, pa tudi na slabotne stare ljudi, ki ne morejo od doma. Inštitut za študije o starejših je bil uspešen tudi pri delu s starejšimi iz nekaterih etničnih manjšsin. Z njimi so se posvečali kuhanju, prehranskim navadam, vedi o prehrani, zdravju.

Projekti za razvoj prostovoljstva obsegajo usposabljanje za pomoč osebam s poškodovano hrbtenico, strokovno vodenje po mestu, individualno uvajanje starejših $v$ rabo ra- 
čunalnika (en mentor, en slušatelj) in Torkov klub, kjer gre za učenje pisarniških opravil in nudenje pomoči upravi Inštituta.

V projektu, imenovanem $50+$, gre za pomoč starejšim, da pridobijo dopolnilna znanja za opravljanje različnih del. Sem se uvršča vista tečajev za osebnostno rast in osebna pomoč prostovoljcev, ki starejšim, iščočim delo, nudijo vrsto osebnih nasvetov. Inštitut nudi tudi pomoč za razvoj podjetništva.

Inštitut, podobno kot Slovenska univerza za tretje življenjsko obdobje, prireja tudi izobraževanje iz geragogike pa tudi tisto za ljudi, ki poklicno delajo s starejšimi, denimo za socialne delavce, negovalce, nosilce gospodinjske pomoči, zaposlene v javni upravi, andragoge, psihologe, terapevte, kadrovske delavce, arhitekte ... Pridobljena znanja na Inštitutu združijo v program, ki vodi v pridobitev javno priznanega spričevala.

V sodelovanju s Škotskim Svetom za potrošništvo, organizacijo Age Concern Scotland in različnimi oddelki Univerze Strathclyde nastajajo študije o vprašanjih starejših. Nedavno so ustanovili tudi Škotski raziskovalni forum za staranje (angl. Scottish Research Forum on Ageing). Mnoge študije so posvečene vplivu učenja starejših na starejše same in druge rodove, na zdravje starejših, na zmanjšanje obsega zdravstvenih in socialnovarstvenih stroškov, na rabo informacijske tehnologije. Tudi Slovenska univerza za tretje življenjsko obdobje je doslej opravila veliko raziskovalnega dela, denimo o izobraževanju starejših $v$ njihovih poznejših letih, življenjskih zgodbah starejših in njihovem vplivu na njihovo izobraževanje, o starejših delavcih, izobraževanju v domski oskrbi ipd.

\section{IZOBRAŽEVANJE STAREJŠIH JE DELO, NE PA KRAMLJANJE IN DRUZZENJE}

V brošuri, ki predstavlja Inštitut za študije o starejših, zasledimo naslednje poglavitne cilje njegovega delovanja, in sicer: (1) da spodbuja nenehno osebnostno rast in intelektualni razvoj starejših; (2) da omogoči starejšim pridobljeno znanje in življenjske spretnosti uporabiti v vrsti družbeno pomembnih okolij, in sicer kot družinski člani, državljani, prostovoljci ali pa tako, da povečajo svojo zaposljivost in so bolje pripravljeni na menjavo poklicev $\mathrm{v}$ delovnih okoljih, (4) da omogoči starejšim vpisati se v redni univerzitetni študij, (5) da Inštitut snuje in podpre raziskovanje o življenju v poznejših letih in širi vedenje o pomenu znanja starejših za družbo.

Ko prebiram te cilje in se spomnim ciljev, ki smo si jih še malce širše zastavili na Slovenski univerzi za tretje življenjsko obdobje, tedaj se nehote nasmehnem. Že dvajset let in več poslušamo večno razmišljanje strokovnjakov, politikov pa tudi naključnih sogovornikov o tem, da se starejši učijo zaradi druženja ..., zato da imajo kaj početi ... Nepremagljivi se tako zdijo stereotipi o starejših pa tudi nenazadnje o izobraževanju odraslih. V državah, ki so še nedavno bile izrazito industrijske, smo namreč prejeli "znanja za industrijo". Vrednote so bile industrijske. Vse je bilo posvečeno delu. Zdi se, da se ne moremo posloviti od prepričanja, da se človek uči zgolj za delo. Starejši pa so največkrat $v$ pokoju, zakaj bi se potemtakem morali učiti? $\mathrm{V}$ informacijski družbi se delo prepleta $\mathrm{z}$ življenjem, v nastajajoči subsidiarni državi se pristojnosti prenašajo na ljudi. Še več, za vsa vsakdanja vprašanja bomo, po projekcijah, imeli na razpolago le izvedence svetovalce, probleme bomo morali videti in reševati sami, vse življenje. ${ }^{3}$

\section{PODOBNI PROGRAMI, RAZLIČNI PROGRAMI}

Pahljača programov za starejše je na tem Inštitutu razmeroma podobno široka in celo podobno zasnovana kot na Slovenski univerzi 
za tretje življenjsko obdobje. Ob rednem programu se pojavljajo še občasne akcije, kot denimo tista, ki so jo izvedli skupaj z delodajalci in so jo poimenovali "Starajmo se pozitivno". Na Slovenskt univerzi smo podobno razvili programe za delodajalce, $v$ katerih prikažemo pomen starejših delavcev za dobro politiko zaposlovanja v podjetju.

Leta 1992 so na Škotskem spričo neugodnih gospodarskih razmer mnoge starejše odpustili. Pa so se ušteli, kajti mladih je zaradi zmanjšanega števila rojstev vse manj in manj ... In zdaj se podjetja na moč trudijo, da bi se starejši znova zaposlili ... Tako na Inštitutu dopolnilno izobražujejo starejše, željne dela. Še več, za podjetje je težko, če se njihovi delavei želijo izobraževati v delovnem času. In tako so na Inštitutu uvedli program "Recruitment and Job Retention" (slov. "Zaposlovanje novih delavcev in ohranjanje dela"). Tiste, ki gredo na izobraževanje, pri delu zamenjajo starejši ... Velikokrat jih tako zaposlijo tudi za daljši čas. Praktično! Toda v ta namen starejši potrebujejo dopolnilna znanja. Job Retention se je razvil tudi v široko zastavljen evropski program.

Zanimiva se mi je zdela tudi malce marketinško obarvana "ponudba" programov, ki so jih poimenovali Šest najboljših. Gre za predavanja, ki tečejo ob ponedeljkih, šest tednov: Sedem najboljših španskih slikarjev (npr. Velasquez, Murillo, Goya), Šest najboljših antičnih dram $\mathrm{v}$ povezavi $\mathrm{z}$ vprašanjem moralne slepote, Šest najboljših poti po Glasgowu s pogledom na najlepše zgradbe v mestu, Besedila šestih najboljših francoskih pevk, denimo Edith Piaf, Patricie Kaas, Šest najboljših arheoloških odkritij ...

\section{STAROST IN USTVARJALNOST}

Tako se je imenovala konferenca, ki jo je Škotski odbor za umetnost pripravil skupaj z Univerzo Strathclyde in Inštitutom za študije o starejših. Konferenca, na kateri so o pomenu umetnosti in ustvarjanja za starejše in vse generacije spregovorili starejši sami. Ljudje različnih let, socialnega porekla, različne izobrazbe, ki pa jih vse druži želja razumeti in ustvarjati lépo. Ob glasbi Boba Dylana je nekdanja univerzitetna profesorica, ki se je komaj v starosti pričela učiti slikati, povedala, da se na stare ljudi lepijo mnogi stereotipi, ona pa pozna še enega: da znanstvenik ne more biti umetnik. $\mathrm{Pa}$ je pričela slikati podobe, $\mathrm{ki}$ spominjajo na kemične formule in atome, ki so si pod njenim čopičem nadeli čudovite barve in oblike.

Konferenco so spremljali mnogi video posnetki. Skupina starejših za video ustvarja fílme, uči se pisati scenarije, režirati filme, montirati. Tako smo bili deležni mnogih scen iz življenja, umetniškega delovanja in učenja starejših. Nekaj podobnega smo poznali tudi $v$ Sloveniji s skupino Mediji in novinarstvo, ki se je učila novinarstva, pisala, oblikovala in izdajala je revijo Tretješolec, pripravljala je novinarske konference, snovala je radijske in televizijske oddaje.

Skupina $G 8$, oblečena v črne drese in dolge črne razvlečene majice, se je $\mathrm{z}$ modernim plesom pričela ukvarjati šele nedavno. Uspešno, četudi 70 let ni ravno idealna starost za prve korake v izraznem plesu. Skupina, $k i$ se uči pripovedovati zgodbe (angl, Story Telling Group) in Skupina, ki se uči brati drame (angl. Drama Reading Group) sta v dialogu predstavili program, ki poteka za starejše skupaj s starejšimi in mladimi mentorji, in sicer v opuščeni hiši ob razburkanem sivem morju. Hay Day se imenuje ta program in v mestecu Saint Andrews ga poznajo prav vsi. Vsako sredo in vsako uro se tu izmenjajo dejavnosti za starejše. Če ne morete priti ob 10. uri, pridete ob 11, če ne zmorete ob 11. uri, pridete na razpravo pri kosilu ob 12 . uri. In tako sleherno sredo. Organizatorjem v 
pomoč je Oddelek mestne občine za umetnost.

V popoldanskem času so se zvrstile številne delavnice, med drugim tistá, ki jo pripravlja BBC o tem, kako so nekoč ljudje doživljali vojno, pa tudi o tem, kako si predstavljajo prihodnost.

\section{Z BRIANOM PO GLASGOWU}

Glasgow ima prelepe viktorijanske zgradbe, ki jih zdaj obnavljajo, kajti $v$ očeh njegovih prebivalcev so postale nadyse dragocene. $\mathrm{V}$ dolini reke Clyde najdemo mnoge primere industrijskega turizma, ki bi jih bilo moč posnemati, denimo v Trbovljah, Hrastniku, Zagorju. Ima pa Glasgow tudi vzoren Mestni turistični urad. Kar tam sem odkrila študijo o Življenju v glasgowskih najemniških stanovanjih od leta 1900 do leta 1945. Pripoved o tem, kako so ljudje živeli v svojih bivališčih; kako so jih urejali, kakšne slike so visele po stenah, kje je stal zaboj za premog, v kakšnih posteljah so spali. V visokih, zaprtih posteljah, kjer je zmanjkovalo zraka, tako da so jih kasneje z zakonom prepovedali. Kaj so jedli, kako so se kopali ipd. Zanimiva študija! Zdaj jo uporabljam v Študijskem krožku za angleški jezik na Slovenski univerzi za tretje življenjsko obdobje. Veliko je možnosti za primerjavo! Če so v Glasgowu nad otroško posteljo nekoč neizogibno visele podobe divjih rac, so pri nas visele podobe angelov, mostu in reke, ki je upodabljala življenje. Če so tam uporabljali ležišča iz ličkanja, so jih pri nas tudi, pa še konjsko žimo. In ležišče je bilo $v$ treh delih. Zlagoma zdaj $\mathrm{v}$ angleščini nastaja pripoved o tem, kako smo živeli nekoč.

Včasih, ko mi pričnejo naporna potovanja presedati, se vprašam, čemu? In vendar vem, da novo nastaja le po tistem, ko smo kaj prebrali, videli, ko smo koga srečali, kaj raziskali. In nastajalo bo vse do takrat, ko bodo naše kulture drugačne in bomo lahko drug drugemu $v$ navdih.

\section{LITERATURA}

Anon (2002): Being Positive About Age Diversity At Work. Department for Work and Pensions, ref. AGE4. London: Crown Copyright.

Hector F., Jean, V. L. (1990); Up Oor Close, Memories of Domestic Life in Glasgow Tenements, 1910-1945. The Springburn Museum Trust and White Cockade.

Hart, L. A. (2001). Senior Studies Institute, Glasgow: University of Strathclyde, December.

wwwage positive.gov.uk

Doc, dr. Dušana Findeisen

I Podobno je še pred nekaj desetletji veljalo za ženske. Še več, ženske so imele tudi prav malo moških vrlin. Tako denimo niso bile sposobne prïjateljstva, če naj verjamemo Montaignu in drugim, pa Iudi učljive naj ne bi bile! Njihove vrline naj bi bile le tiste, ki so sluz̃ile moškim. Podobno je danes edina resnično priznana vrlina starejsih, da so lahko dobri stari starš̌i vtrokom generacije, ki ima največjo družbeno moč in odloča o družbenih vprasanjih.

2 Mlada novinarka je vztrajno ponavljala vprašanje: "Gospod, zakaj se vi učite pri teh letih ...?" Nikakor ni mogla razumeti, zakaj je določilo "pri teh letih" odveč.

3 Nedavno sem v Parizu prisostvovala predavanju o bolnišnici prihodnosti. Raziskovalci so si postavili vprašanje, ali bomo leta 2010 še imeli sestre, ki bodo negovale rakave bolnike, ali bomo se imeli splošne ambulante ... Napovedujejo, da bo bolnišnica z dosti manj osebja delovala predusem kot svetovalna ustanova in pridobiti si bomo morali številna znanja, da bomo znali nasvet poiskati in ga tudi uporabiti. V vseh starostih, seveda. 